\title{
Morphology of the submandibular gland's acini of rats in diabetes mellitus
}

\author{
N. S. Tokaruk ${ }^{B, C, F}$, O. H. Popadynets ${ }^{A, E, F}$, V. I. Bedei ${ }^{B, C}$, M. I. Hryshchuk ${ }^{\mathbb{C}, F}$, \\ T. L. Kotyk (D)*A,D,E
}

Ivano-Frankivsk National Medical University, Ukraine

A - research concept and design; B - collection and/or assembly of data; C - data analysis and interpretation; D - writing the article; $\mathrm{E}$ - critical revision of the article; $\mathrm{F}$ - final approval of the article

Key words: seromucocytes, salivary gland, streptozotocin, microanatomy, pathology.

Pathologia 2020; 17 (3), 384-389

*E-mail: tkotyk@ifnmu.edu.ua
Aim. The purpose of the study was to determine the morphological changes in seromucous acini of the submandibular gland in experimental rats with diabetes mellitus.

Material and methods. The experiment was performed with 1-year-old male Wistar rats. Experimental diabetes mellitus was induced by a single intraperitoneal administration of streptozotocin. Ultrastructural changes in the seromucous cells of the submandibular gland were studied during the $14^{\text {th }}, 42^{\text {nd }}$ and $70^{\text {th }}$ days of the experiment.

Results. In experimental diabetes mellitus in the seromucous cells of the submandibular gland hypertrophy of the rough endoplasmic reticulum and the Golgi complex; vacuolization of the cytoplasm; a large number of intracellular laminated structures and lysosomes; diffuse homogenization of the matrix, destruction of mitochondrial cristae and vacuolization of mitochondria were observed and the most pronounced on the $14^{\text {th }}$ day. On the $70^{\text {th }}$ day of the experiment the seromucous cells are characterized by the absence of morphological signs of damage and the development of atrophy and it is confirmed by the reduction in cells' size as well as the normalization of the relative area of secretory granules.

Conclusion. The obtained data indicate that the reaction of the cells of seromucous acini to the development of hyperglycemia is typical and nonspecific. Thus, the alternative changes have a pronounced dystrophic character in the early stages and increase to the $42^{\text {nd }}$ day of the experiment. On the $70^{\text {th }}$ day histologic adaptation of the seromucous acini was observed and approved by atrophic changes, decrease of cells' area and normalization of the relative area of their granules.

\section{Ключові слова:} серомукоцити, слинна залоза стрептозотоцин, мікроанатомія, патологія.

Патологія. 2020.

T. 17, № 3(50).

C. 384-389

\section{Морфологія кінцевих відді^ів підщелепної залози щурів при цукровому діабеті}

\section{Н. С. Токарук, О. Г. Попадинець, В. І. Бедей, М. І. Грищук, Т. А. Котик}

Мета роботи -встановити морфологічні зміни серомукозних ацинусів підщелепної залози щурів з експериментальним цукровим діабетом.

Матеріали та методи. Експеримент виконали на однорічних самцях щурів лінії Wistar. Експериментальний цукровий діабет індукували одноразовим внутрішньоочеревинним уведенням стрептозотоцину. Ультраструктурні зміни в серомукоцитних клітинах підщелепної залози вивчали на 14, 42 і 70 добу експерименту.
Результати. У разі експериментального цукрового діабету в серомукоцитах підщелепної залози спостерігали гіпертрофію ендоплазматичного ретикулуму та комплексу Ґольджі, вакуолізацію цитоплазми, велику кількість внутрішньоклітинних пластинчастих структур і лізосом, дифузну гомогенізацію матриксу, руйнування мітохондріальних крист і вакуолізацію мітохондрій, що були найбільш виражені на 14 день. На 70 день експерименту серомукоцити характеризувалися відсутністю морфологічних ознак пошкодження, спостерігали розвиток атрофрії, що підтверджується зменшенням розміру клітин, а також нормалізацією відносної площі секреторних гранул.

Висновки. Результати свідчать, що реакція гландулоцитів серомукозних ацинусів на розвиток гіперглікемії типова та неспецисрічна. Альтеративні зміни мають виражений дистрофічний характер на ранніх стадіях і збільшуються до 42 дня експерименту. На 70 добу спостерігали гістологічну адаптацію серомукоцитів, що підтверджується розвитком атрофічних змін, зменшенням площі клітин і нормалізацією відносної площі їхніх гранул.

Ключевые слова: серомукоциты, слюнная железа, стрептозотоцин, микроанатомия, патология.

\section{Морфология конечных отделов поднижнечелюстной железы крыс при сахарном диабете}

\section{Н. С. Токарук, О. Г. Попадинец, В. И. Бедей, М. И. Грищук, Т. А. Котик}

Цель работы - исследовать морфологические изменения в серомукозных ацинусах подчелюстной железы крыс с экспериментальным сахарным диабетом.

Материалы и методы. Эксперимент провели на однолетних самцах крыс линии Wistar. Экспериментальный сахарный диабет индуцировали одноразовым внутрибрюшинным введением стрептозотоцина. Ультраструктурные изменения в серомукоцитах подчелюстной железы изучали на 14, 42 и 70 сутки эксперимента. 
Результаты. При экспериментальном сахарном диабете в серомукоцитах подчелюстной железы наблюдали гипертрофию эндоплазматического ретикулума и комплекса Гольджи, вакуолизацию цитоплазмы, большое количество внутриклеточных пластинчатых структур и лизосом, диффузную гомогенизацию матрикса, разрушение митохондриальных крист и вакуолизацию митохондрий, наиболее выраженные на 14 сутки. На 70 сутки эксперимента для серомукоцитов характерно отсутствие морфологических признаков повреждения и развитие атрофии, что подтверждается уменьшением размера клеток, а также нормализацией относительной площади секреторных гранул.

Выводы. Результаты свидетельствуют, что реакция серомукоцитов на развитие гипергликемии типична и неспецифична. Альтеративные изменения имеют выраженный дистрофический характер на ранних стадиях и увеличиваются к 42 дню эксперимента. На 70 сутки отмечена гистологическая адаптация серомукоцитов, которая подтверждается развитием атрофических изменений, уменьшением площади клеток и нормализацией относительной площади их гранул.

A number of studies has found that there is a correlation between diabetes mellitus (DM) and dental pathology including the dysfunction of the salivary glands [1-4]. Diagnostic of salivary gland dysfunction is rather difficult in clinical practice and based on systematic patient examination [5]. The submandibular gland (SMG) is the main source of basal salivary secretion [6,7]; hence, the abnormalities in the functioning of its seromucous acini play the leading role in the development of hyposalivation and xerostomia [8]. Such correlation between the salivary glands and DM confirms a clear association between hyperglycemia and oral health status, thereby indicating the relevance of studying SMG.

It should be noticed, main function of acinar cells is primary saliva production. Its base is secretory cycle and consists of receiving substances, synthesis, storing and eliminating of secretory granules. During secretory cycle, volume of cells and their secretory granules changes as main volume of primary saliva is accumulated and then is excreted under different stimuli such as food, autonomic nerve stimulation, etc. $[9,10]$.

A lot of researches highlight changes of the acini of SMG, which are seromucous in rats [11], under influence of DM [11-16]. At the same time, structural normalization of the seromucous cells of SMG (except hypertrophy of the rough endoplasmic reticulum) was indicated in Wistar rats after 3 weeks of hyperglycemia [12].

According to [13], volume of the acini of SMG did not undergo any changes after 4 weeks after streptozotocin-induced diabetes. However, on electron microscopic level, autophagosomes and lysosomes were often detected [14].

Impact of streptozotocin-induced hyperglycemia during 6-7 weeks leads to salivation decrease almost twofold and reducing the activity of salivary amylase more than fivefold [15]. Also, dystrophic changes of SMG acini was found [16] after 8 weeks of experimental DM. However, structural normalization of the seromucous cells and the reduction of their size were observed over a 2-month period of hyperglycemia [12].

Summarizing all the aforementioned information, it can be affirmed that experimental DM is accompanied by disturbances in the metabolism and antioxidant status of the seromucous cells. The results of morphological studies [11-16] are often controversial; although, they indicate the development of dystrophic changes, but differ in experimental design, lines of rats and their initial age, the duration of hyperglycemia exposure. All these factors lead to the difficulties when comparing the results of the features of morphological changes of the seromucous acini in experimental hyperglycemia.

\section{Aim}

The objective of research was to determine chronological dependence between morphological changes in seromucous acini of SMG and duration of the experimental DM.

\section{Materials and methods}

The study included 1-year-old male Wistar rats which were divided into 2 groups: the experimental ( $n=15$ animals) and the control ( $n=15$ animals). DM was induced by an intraperitoneal administration of streptozotocin $(60 \mathrm{mg} / \mathrm{kg}$ body weight) dissolved in cold citrate buffer $\mathrm{pH} 4.5$. Animals of the control group were injected with an equivalent amount of citrate buffer only. The development of DM was proved by monitoring of glucose level in the blood (fasting blood samples was collected from tail vein and measured by glucometer Accu-Check Active, Roche Diagnostics $\mathrm{GmbH}$, every day during experiment). Animals, having fasting blood glucose concentration over $12 \mathrm{mmol} / \mathrm{l}$ were considered as diabetic ones.

The samples were collected in the morning, before food intake, on the $14^{\text {th }}, 42^{\text {nd }}$ and $70^{\text {th }}$ days after an overdose of thiopental (5 animals per group).

The left SMG was excised and fixed in $10 \%$ buffered paraformaldehyde solution $(\mathrm{pH}=7.4)$, embedded in paraffin. Paraffin sections were stained with hematoxylin and eosin, examined with light microscope Micros Austria MC300 and photographed with ToupCam 5.1M UHCCD C-Mount Sony.

The right SMG was removed and fixed in $2.5 \%$ glutaraldehyde solution with followed post-fixation in $2 \%$ osmium tetroxide $\left(\mathrm{OsO}_{4}\right)$ solution for electron microscope examination. Electron microscopy was performed with PEM-125K.

Morphometry was conducted in ImageJ2 [17], as it allows to perform image analysis in semi-automatically mode using build-in macro language [18]. On histological sections the area of the seromucous cells were measured. On transmission electron micrographs of the seromucous cells, the RA of their secretory granules was determined semi-automatically (algorithm is developed by us). The main point of the developed algorithm was as follows:

1. The contours of the seromucous cell were outlined (manually) using the command "Fit Spline" (Fig. 1a);

2. The area outside the current image selection was erased to the background color (the command "Clear Outside"). Using the command "Threshold" (method "IJ_IsoData dark", the maximum threshold value was 254; the minimum threshold value was automatically adjusted) secretory granules were covered by the mask (Fig. 1b); 


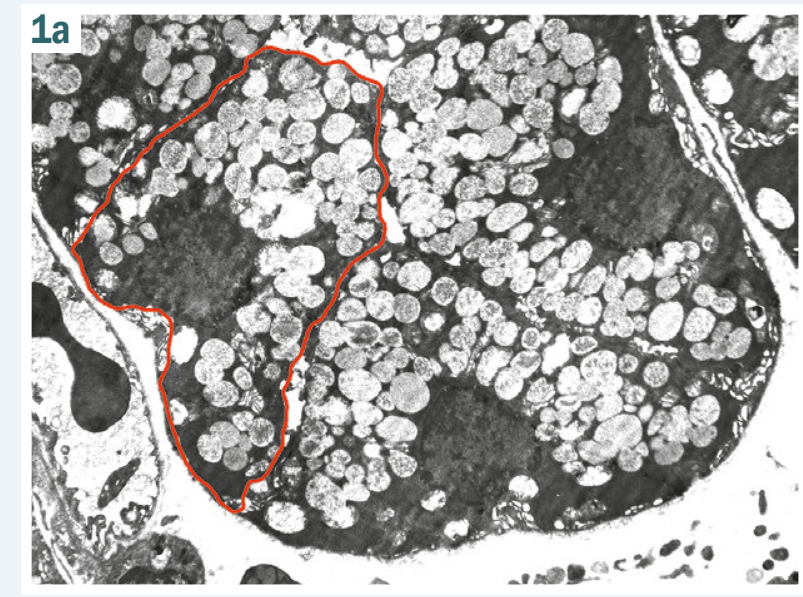

1b

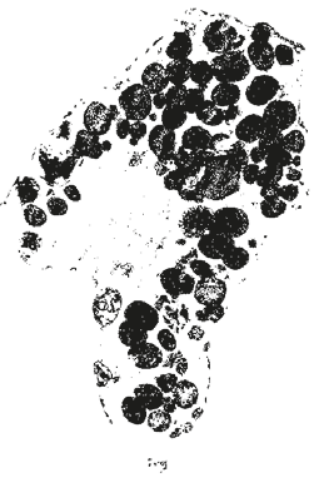

1c
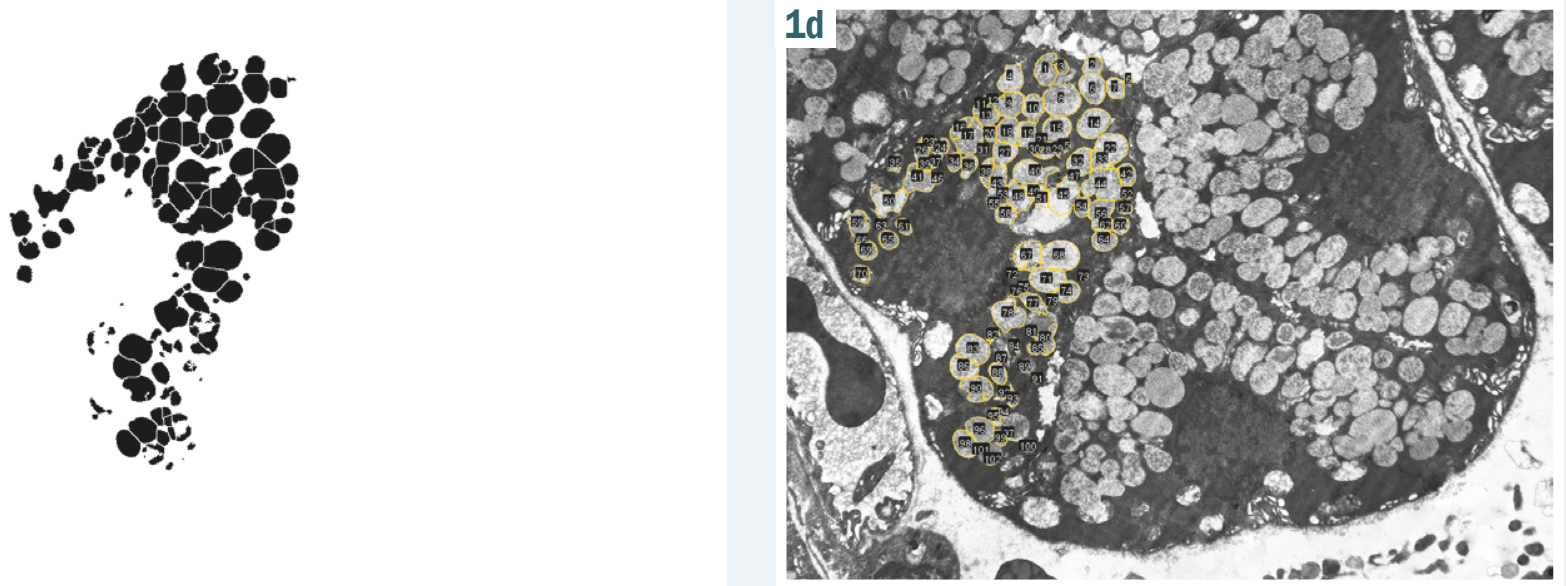

Fig. 1. Stages of the algorithm for determining the area of the seromucous cells granules. a, b, c, d represent the results of stages $1,2,3$ and 4 of this algorithm (explanation in the text).

3. Outliers were removed (the command "Remove Outliers"), there were used binary operator Close (iteration $=5 \&$ count $=3$ ) and the "Watershed" and "Fill Holes" commands (Fig. 1C);

4. "Analyze Particles" module was used to determine the area of particles with a circularity of 0.5 to 1.0 (determined empirically) (Fig. 1d).

Basing on $[7,9,10]$, such morphometric parameters have been chosen as indicators of the secretory activity of the cells.

Statistical analysis was conducted using R software [19]. Results of the descriptive statistics are shown as Mean \pm SD. The data of independent groups were compared using the Mann-Whitney-Wilcoxon test; the difference was considered statistically significant at $\mathrm{P}<0.05$.

Ethical approval. The experiment was carried out in accordance with EU Directive 2010/63/EU for animal experiments.

\section{Results}

The $14^{\text {th }}$ day after streptozotocin administration. On the background of hyperglycemia (blood glucose level was $14.02 \pm 1.20 \mathrm{mmol} / \mathrm{l}$ and exceeded that in the control group 2.74-fold, $P<0.01$ ), the seromucous cells with large vacuoles were seen (Fig. 2a). There were round nuclei with small invaginations of the nuclear membrane and predominant euchromatin; heterochromatin seen in the form of clumps was mainly marginally distributed; the perinuclear space was identified around the perimeter; the extended perinuclear space was occasionally seen. The seromucous cells with hypertrophied rough endoplasmic reticulum (RER) and Golgi complex (GC) were prevalently observed (Fig. 2b). The cisternae of the GC were often dilated. Mostly elongated mitochondria of different sizes with unclear cristae were found at the cell periphery. In single cells, autolysosomes and intracellular laminated structures were detected. The areas containing disorganized, vacuolated, dilated cisternae of the RER and a lower number of ribosomes attached to their surfaces were occasionally seen.

It was morphometrically determined that during this observation period the area of the seromucous cells did not differ from that in the control group $(P>0.05$, Table 1). The RA of secretory granules reduced 1.42 -fold compared to control values $(P<0.001)$.

The $42^{\text {nd }}$ day of experiment. The seromucous cells containing a low number of secretory granules were identified (Fig. 3a), their RA was 1.37 times lower than control values $(P<0.01)$. The cisternae of the RER and GC were dilated. Mitochondria were mostly rounded; the destruction of their cristae and homogenization of 

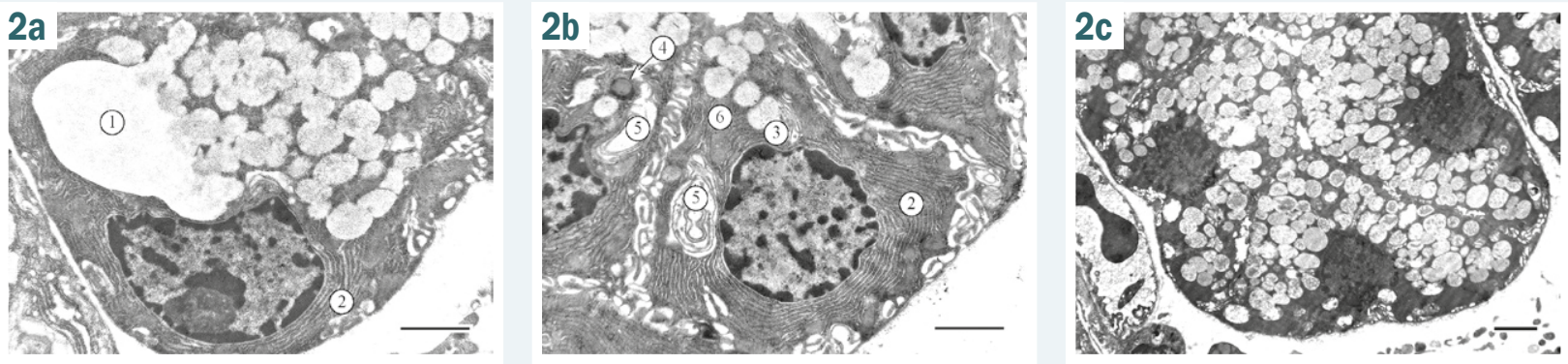

Fig. 2. Morphological changes in the seromucous cells on the $14^{\text {th }}$ day of the experiment. a: vacuolization of the cytoplasm, b: hypertrophy of the rough endoplasmic reticulum and Golgi complex, c: control group. Scale bar $2 \mu \mathrm{m}$. Labels: 1 -vacuole; 2 -hypertrophy of the rough endoplasmic reticulum; 3 -hypertrophy of the Golgi complex; 4 -autolysosome; 5 - intracellular laminated structures; 6 - mitochondria.
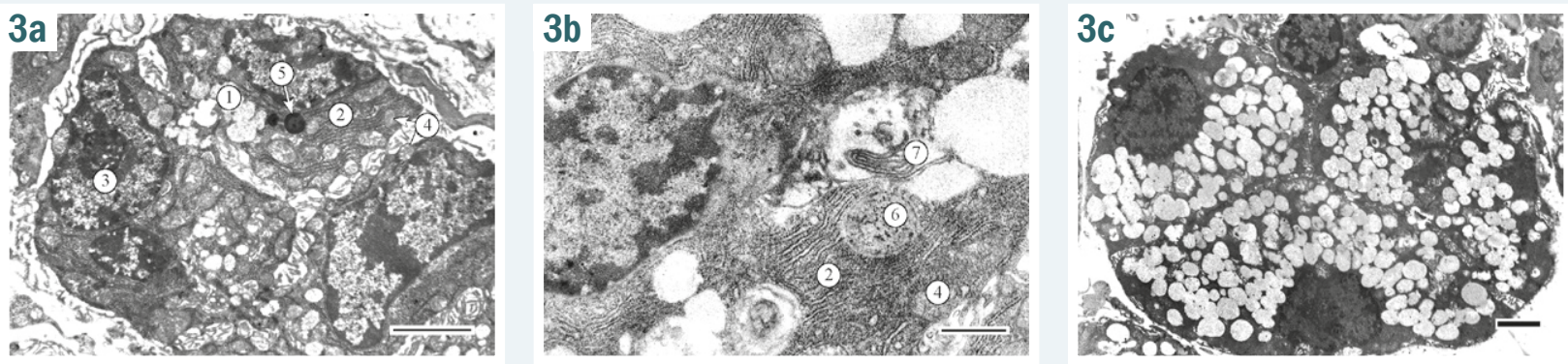

Fig. 3. Pathological changes in the seromucous cells on the $42^{\text {nd }}$ day of the experiment (a, b). c: control group. Scale bar: a, c: $3 \mu \mathrm{m}, \mathrm{b}: 1 \mu \mathrm{m}$. Labels: $1-$ secretory granules; 2 rough endoplasmic reticulum; 3 - nucleus; 4 - mitochondria; 5 -autolysosome; 6 - phagolysosome; 7 - intracellular laminated structures.
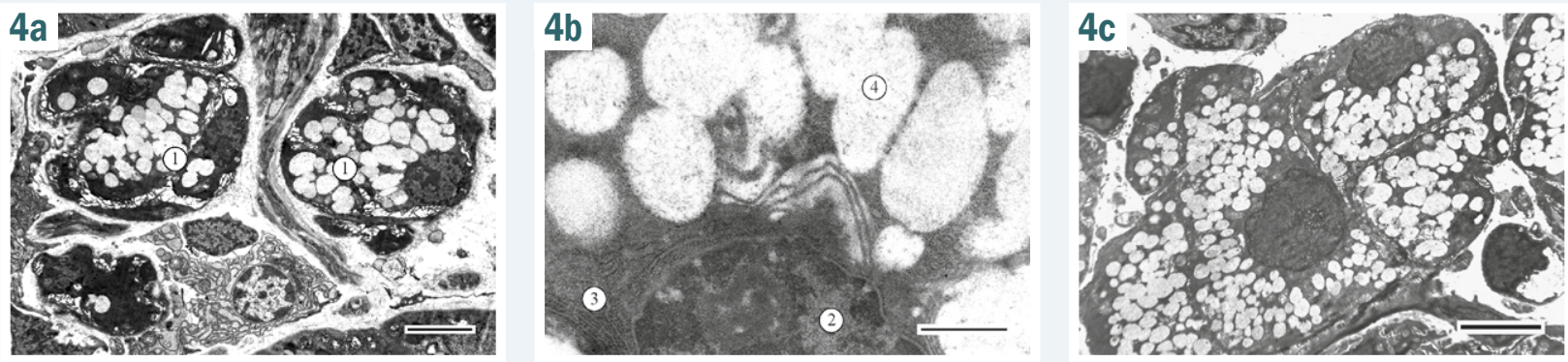

Fig. 4. Overgrowth of glandular stroma, atrophy of the seromucous cells (a) and their rough endoplasmic reticulum, Golgi complex (b). c: control group. Scale bar: a, c: $5 \mu$ m, b: 1 $\mu \mathrm{m}$. Labels: 1 - atrophic seromucous acini; 2 - nucleus; 3 -rough endoplasmic reticulum; 4 - secretory granules.

the mitochondrial content were observed. The perinuclear space was not clearly identified around the perimeter of the nucleus; the vesicles transporting lysosomal enzymes, heterolysosomes and autolysosomes were seen (Fig. 3a,b).

On the $42^{\text {nd }}$ day, on the background of the increase in blood glucose level $(23.88 \pm 3.16 \mathrm{mmol} / \mathrm{l})$ which exceeded that in the control group 4.68-fold $(P<0.001)$, the area of the seromucous cells reduced 1.15 -fold $(P<0.001)$ compared to the control group (Table 1).

The $70^{\text {th }}$ day after streptozotocin administration. Numerous areas of the overgrowth of glandular stroma were seen (Fig. 4a). The seromucous acini were formed by small seromucous cells, the nuclei of which contained mostly euchromatin; heterochromatin was located under the nuclear membrane. The perinuclear space was preserved; the extended perinuclear space was occasionally observed. Only few cisternae of the RER and GC were seen (Fig. 4b). Mitochondria of different sizes and shapes with clear cristae and the enlightened matrix were found at the cell periphery. The vesicles transporting
Table 1. Area of the seromucous cells $\left(\mu \mathrm{m}^{2}\right)$ and relative area of their secretory granules in the rat submandibular gland during different time periods (Mean $\pm \mathrm{SD}$ )

\begin{tabular}{l|l|l|l|}
$\begin{array}{l}\text { Time period, } \\
\text { day }\end{array}$ & Animals & $\begin{array}{l}\text { Area of seromucous } \\
\text { cells, } \mu^{2}\end{array}$ & $\begin{array}{l}\text { Relative area of } \\
\text { granules }\end{array}$ \\
\hline $14^{\text {th }}$ & Control & $120.23 \pm 22.82$ & $0.44 \pm 0.05$ \\
& Experimental & $124.62 \pm 34.36$ & $0.31 \pm 0.12^{* *}$ \\
\hline $42^{\text {nd }}$ & Control & $123.55 \pm 23.56$ & $0.48 \pm 0.05$ \\
& Experimental & $107.47 \pm 25.41^{* *}$ & $0.35 \pm 0.16^{*}$ \\
\hline $70^{\text {th }}$ & Control & $115.79 \pm 21.36$ & $0.45 \pm 0.04$ \\
& Experimental & $69.44 \pm 16.58^{* *}$ & $0.42 \pm 0.09$ \\
\hline
\end{tabular}

$*, * *$ : the level of statistical significance achieved in comparison with the control group, $\mathrm{P}<0.01, \mathrm{P}<0.001$, respectively.

lysosomal enzymes were single; secretory granules were enlightened.

Despite stable level of blood glucose $(22.93 \pm 2.28$ $\mathrm{mmol} / \mathrm{l})$ as compared to the $42^{\text {nd }}$ day $(P>0.05)$, a progressive reduction in the area of the seromucous cells 1.67 fold $(P<0.001)$ was observed (Table 1 ), while the RA of secretory granules rapidly increased and did not differ from control values on the $70^{\text {th }}$ day of the experiment $(P>0.05)$. 


\section{Discussion}

In streptozotocin-induced diabetes, on the background of dynamic increase in the levels of blood glucose, pronounced dystrophic changes in seromucous cells being characterized by vacuolization of the cytoplasm, a large number of lysosomes, intracellular laminated structures, mitochondria with vacuolated content and crista destruction were observed during the early observation periods (on the $14^{\text {th }}-42^{\text {nd }}$ days of the experiment). Moreover, hypertrophy of the RER and GC cisternae were present. Such morphological changes indicate changes in the cells' condition and, probably indicates the activation of compensatory mechanisms, cells' swelling and damage, and, as a result, the abnormalities in the processes of secretion $[20,21]$. Similar changes in the seromucous cells of SMG in streptozotocin-induced diabetes were observed by Mednieks et al. [14]. At the same time, 3 weeks after streptozotocin administration, most seromucous cells are characterized by normal ultrastructure without significant pathological changes, except for the increase in the amount of the RER [12]. In our opinion, such differences occurred due to the fact that we have used 1-year-old male rats, because initial age has an important effect on experimental results [22]. The dynamics of morphometric parameters deserves special attention. On the $14^{\text {th }}$ day, the RA of secretory granules reduced while there were no statistically significant changes in the sizes of cells. In our opinion, it indirectly point out a potential predominance of the processes of eliminating secretion and additionally confirms the activation of compensatory mechanisms aimed at preserving secretory ability. On the $42^{\text {nd }}$ day of observation, the area of the seromucous cells as well as the RA of their secretory granules was smaller compared to the control group. Alongside with detected morphological changes, in our opinion, it is the result of decreased activity of the synthesis processes as well as the elimination of secretion on the background of the hyperglicemia and diabetic microangyopathy [23,24].

In the last observation period (the $70^{\text {th }}$ day), blood glucose levels in animals of the experimental group were stable. The seromucous cells contained single vesicles transporting lysosomal enzymes; the reduction in size of the RER and GC cisternae was observed. Generally, no pronounced morphological signs of damage to the seromucous cells were observed. Mitochondria with clear cristae and the enlightened matrix were identified. Occurred atrophy of studied cells and their organelles, the RER and GC in particular, are morphometrically confirmed by a progressive reduction in size of the seromucous cells. We consider such structural organization of the seromucous cells to indicate the formation of their histological adaptation to chronic hyperglycemia which is additionally confirmed by the increase in the RA of secretory granules reaching normal values on the $70^{\text {th }}$ day. Atrophy of the seromucous acini of SMG was identified on the background of the stromal component significant overgrowth in NOD mice in the early stages of autoimmune diabetes [25]. It should be noted that the phenomenon of atrophy of SMG seromucous acini was observed after 5-15 months of chronic ethanol intoxication [26] and postmenopausal rats with diabetes [11]. In our opinion, it confirms the fact that atrophy of the seromucous cells can be considered as a nonspecific response to the impact of alterant factor. Furthermore, such response develops in different time periods emphasizing the significance of genesis, the intensity and duration of the impact of damaging agent on the functioning of SMG seromucous cells.

\section{Conclusions}

The obtained data indicate that the reaction of seromucous cells to the development of hyperglycemia is typical and nonspecific. Thus, the alteration changes have a pronounced dystrophic character in the early stages and increase to the $42^{\text {nd }}$ day of the experiment. On the $70^{\text {th }}$ day histologic adaptation of the seromucous acini was observed and approved by atrophic changes, decreasing area of cells and normalization of the relative area of their granules.

Conflicts of interest: authors have no conflict of interest to declare. Конфмікт інтересів: віАсутній.

Надійшла Ао редакції / Received: 20.10.2020

Після Аоопрацювання / Revised: 02.11.2020

Прийнято Ао Аруку / Accepted 16.11.2020

Informations about authors:

Tokaruk N. S., MD, PhD, Associate Professor, Department of Human Anatomy, Ivano-Frankivsk National Medical University, Ukraine.

ORCID ID: 0000-0003-1404-7857

Popadynets 0. H., MD, PhD, DSc, Professor, Head of the Department of Human Anatomy, Ivano-Frankivsk National Medical University, Ukraine.

ORCID ID: 0000-0002-2093-5984

Bedei V. I., Laboratory Assistant of the Department of Human Anatomy, Ivano-Frankivsk National Medical University, Ukraine. ORCID ID: 0000-0001-9732-3065

Hryshchuk M. I., PhD, Associate Professor, Department of Human Anatomy, Ivano-Frankivsk National Medical University, Ukraine.

ORCID ID: 0000-0001-9202-295X

Kotyk T. L., MD, PhD, Associate Professor, Department of Human Anatomy, Ivano-Frankivsk National Medical University, Ukraine. ORCID ID: 0000-0002-3585-2356

\section{Відомості про авторів:}

Токарук Н. С., канА. меА. наук, Аоцент каф. анатомії пюАини, Івано-Франківський національний медичний університет, україна.

Попадинець О. Г., А-р меА. наук, професор, зав. каф. анатомії ^юАини, Івано-Франківський національний меАичний університет, Україна.

Бедей В. І., лаборант каф. анатомії ^юдини, Івано-Франківський національний медичний університет. Україна.

Грищук М. І., канА. біол. наук, Аоцент каф. анатомії мюдини, Івано-Франківський національний медичний університет, україна.

Котик Т. ^., канА. меА. наук, Аоцент каф. анатомії АюАини, ІваноФранківський національний медичний університет, Україна.

\section{Сведения об авторах}

Токарук Н. С., канА. меА. наук, Аоцент каф. анатомии человека, Ивано-Франковский национальный меАицинский университет, Украина.

Попадинец О. Г., А-р меА. наук, профессор, зав. каф. анатомии человека, Ивано-Франковский национальный медицинский университет, Украина.

Бедей В. И., лаборант каф. анатомии человека, Ивано-

Франковский национальный медицинский университет, Украина. 
Грищук М. И., канА. биол. наук, доцент каф. анатомии человека, Ивано-Франковский национальный меАицинский университет, Украина.

Котик Т. ^., канд. меА. наук, Аоцент каф. анатомии человека, Ивано-Франковский национальный медицинский университет, Украина.

\section{References}

[1] D’Agostino, C., Elkashty, O. A., Chivasso, C., Perret, J., Tran, S. D., \& Delporte, C. (2020). Insight into Salivary Gland Aquaporins. Cells, 9(6), 1547. https://doi.org/10.3390/cells9061547

[2] Sinjari, B., Feragalli, B., Cornelli, U., Belcaro, G., Vitacolonna, E., Santilli, M., Rexhepi, I., D'Addazio, G., Zuccari, F., \& Caputi, S. (2020). Artificial Saliva in Diabetic Xerostomia (ASDIX): Double Blind Trial of Aldiamed $^{\circledR}$ Versus Placebo. Journal of Clinical Medicine, 9(7), 2196. https://doi.org/10.3390/icm9072196

[3] López-Pintor, R. M., Casañas, E., González-Serrano, J., Serrano, J., Ramírez, L., de Arriba, L., \& Hernández, G. (2016). Xerostomia, Hyposalivation, and Salivary Flow in Diabetes Patients. Journal of Diabetes Research, 2016, 1-15. https://doi.org/10.1155/2016/4372852

[4] Navea Aguilera, C., Guijarro de Armas, M. G., Monereo Megías, S., Merino Viveros, M., \& Torán Ranero, C. (2015). The relationship between xerostomia and diabetes mellitus: A little known complication. Endocrinologia y nutricion, 62(1), 45-46. https://doi.org/10.1016/j. endoen.2014.09.008

[5] Pedersen, A. M. L., Sørensen, C. E., Proctor, G. B., Carpenter, G. H. \& Ekström, J. (2018). Salivary secretion in health and disease. Journal of Oral Rehabilitation, 45(9), 730-746. https://doi.org/10.1111/joor.12664

[6] Büttler, R. M., Bagci, E., Brand, H. S., Heijer, M. den, Blankenstein, M. A., \& Heijboer, A. C. (2018). Testosterone, androstenedione, cortisol and cortisone levels in human unstimulated, stimulated and parotid saliva. Steroids, 138, 26-34. https://doi.org/10.1016/j. steroids.2018.05.013

[7] Proctor, G. B., \& Shaalan, A. K. (2018). Salivary Gland Secretion. In Physiology of the Gastrointestinal Tract (pp. 813-830). Elsevier. https:// doi.org/10.1016/B978-0-12-809954-4.00037-2

[8] Araujo, M. V. T., Spadella, M. A., Chies, A. B., Arruda, G. V., Santos, T. M., Cavariani, M. M., \& Domeniconi, R. F. (2018). Effect of low radiation dose on the expression and location of aquaporins in rat submandibular gland. Tissue \& cell, 53, 104-110. https://doi. org/10.1016/j.tice.2018.06.006

[9] Porcheri, C., \& Mitsiadis, T. (2019). Physiology, Pathology and Regeneration of Salivary Glands. Cells, 8(9), 976. https://doi.org/10.3390/ cells8090976

[10] Mese, H., \& Matsuo, R. (2007). Salivary secretion, taste and hyposalivation. Journal of Oral Rehabilitation, 34(10), 711-723. https://doi. org/10.1111/j.1365-2842.2007.01794.x

[11] Seçil, B. B., Parlak, N., Keleş, O. N., Can, I., Yetim, Z., Toktay, E., Selli, J., \& Ünal, B. (2015). Effects of Diabetes on Post-Menopausal Rat Submandibular Glands: A Histopathological and Stereological Examination. The Eurasian Journal of Medicine, 47(3), 199-207. https:/l doi.org/10.5152/eurasianjmed.2015.80

[12] Anderson, L. C., Suleiman, A. H., \& Garrett, J. R. (1994). Morphological effects of diabetes on the granular ducts and acini of the rat submandibular gland. Microscopy Research and Technique, 27(1), 61-70. https://doi.org/10.1002/jemt.1070270105

[13] Noorafshan, A. (2006). Volume-weighted mean volume of the submandibular gland acini in male and female diabetic rats. Micron, 37(7), 613-616. https://doi.org/10.1016/j.micron.2006.03.001

[14] Mednieks, M. I., Szczepanski, A., Clark, B., \& Hand, A. R. (2009). Protein expression in salivary glands of rats with streptozotocin diabetes. International Journal of Experimental Pathology, 90(4), 412-422. https://doi.org/10.1111/i.1365-2613.2009.00662.x

[15] Fedirko, N. V., Kruglikov, I. A., Kopach, O. V., Vats, J. A., Kostyuk, P. G., \& Voitenko, N. V. (2006). Changes in functioning of rat submandibular salivary gland under streptozotocin-induced diabetes are associated with alterations of $\mathrm{Ca} 2+$ signaling and $\mathrm{Ca} 2+$ transporting pumps. Biochimica et Biophysica Acta, 1762(3), 294-303. https://doi. org/10.1016/j.bbadis.2005.12.002

[16] Take, G., Ilgaz, C., Erdogan, D., Ozogul, C., \& Elmas, C. (2007). A comparative study of the ultrastructure of submandibular, parotid and exocrine pancreas in diabetes and fasting. Saudi medical journal, 28(1), 28-35.

[17] Rueden, C. T., Schindelin, J., Hiner, M. C., DeZonia, B. E., Walter, A. E., Arena, E. T., \& Eliceiri, K. W. (2017). ImageJ2: ImageJ for the next generation of scientific image data. BMC Bioinformatics, 18(1), 529. https://doi.org/10.1186/s12859-017-1934-z

[18] Kotyk, T., Dey, N., Ashour, A. S., Anghel Drugarin, C. V., Gaber, T., Hassanien, A. E., \& Snasel, V. (2016). Detection of Dead Stained
Microscopic Cells Based on Color Intensity and Contrast. In Advances in Intelligent Systems and Computing (Vol. 407, pp. 57-68). https://doi. org/10.1007/978-3-319-26690-9 6

[19] R Core Team. (2020). R: A Language and Environment for Statistical Computing. https://www.r-project.org/

[20] Fitzpatrick, S. G., \& Gordon, S. C. (2018). Cell Injury, Adaptation, and Necrosis. In Apoptosis and Beyond (pp. 83-98). John Wiley \& Sons, Inc. https://doi.org/10.1002/9781119432463.ch5

[21] Kumar, V., Abbas, A. K., \& Aster, J. C. (2018). Cell Injury, Cell Death, and Adaptations. In Robbins Basic Pathology (10th ed.).

[22] Scridon, A., Perian, M., Marginean, A., Fisca, C., Vantu, A., Ghertescu, D., Chevalier, P., \& Serban, R. C. (2015). Wistar rats with long-term streptozotocin-induced type 1 diabetes mellitus replicate the most relevant clinical, biochemical, and hematologic features of human diabetes / Sobolanii Wistar cu diabet zaharat tip 1 indus cu streptozotocina reproduc cele mai . Revista Romana de Medicina de Laborator, 23(3), 263-274. https://doi.org/10.1515/rrlm-2015-0028

[23] Carrizzo, A., Izzo, C., Oliveti, M., Alfano, A., Virtuoso, N., Capunzo, M., Di Pietro, P., Calabrese, M., De Simone, E., Sciarretta, S., Frati, G. Migliarino, S., Damato, A., Ambrosio, M., De Caro, F., \& Vecchione, C. (2018). The Main Determinants of Diabetes Mellitus Vascular Complications: Endothelial Dysfunction and Platelet Hyperaggregation. International Journal of Molecular Sciences, 19(10), 2968. https://doi. org/10.3390/ijms19102968

[24] Kotyk, T. (2016). Morphology of the intralobular duct of the submandibular gland in rats in case of experimental diabetes mellitus. Microscopy Research and Technique, 79(12), 1222-1229. https://doi. org/10.1002/jemt.22781

[25] Caldeira, E. J., Camilli, J. A., \& Cagnon, V. H. A. (2005). Stereology and ultrastructure of the salivary glands of diabetic Nod mice submitted to long-term insulin treatment. The Anatomical Record. Part A, Discoveries in Molecular, Cellular, and Evolutionary Biology, 286(2), 930-937. https://doi.org/10.1002/ar.a.20236

[26] Tirapelli, L. F., Tirapelli, D. P. C., \& Tamega, O. J. (2002). Ultrastructural Alterations In Submandibular Glands Of Rats (Rattus Norvegicus) Submitted To Experimental Chronic Alcoholism. Revista Chilena de Anatomía, 20(1), 1-12. https://doi.org/10.4067/S071698682002000100001 